\title{
Complications of Goitre Surgery in "A" Surgery at the Chu of Point G
}

\author{
Moussa Sissoko*, Mahamadou Coulibaly, Oumar Sacko, Sekou Koumaré, Adaman F. Traoré, \\ Soumaîla Keïta, Sidiki Keita, Siaka Diallo, Mossa Camara, Lamine Soumaré, Adama K. Koïta, \\ A. Camara, H. Dicko, D. Goïta, Zimogo Zié Sanogo
}

General Surgery “A” Department, Hospital Point-G., Bamako, Mali

Email: ^moussasissoko208@gmail.com

How to cite this paper: Sissoko, M., Coulibaly, M., Sacko, O., Koumaré, S., Traoré, A.F., Keïta, S., Keita, S., Diallo, S., Camara, M., Soumaré, L., Koïta, A.K., Camara, A., Dicko, H., Goïta, D. and Sanogo, Z.Z. (2021) Complications of Goitre Surgery in "A" Surgery at the Chu of Point G. Surgical Science, 12, 46-52.

https://doi.org/10.4236/ss.2021.123007

Received: October 13, 2020

Accepted: March 7, 2021

Published: March 10, 2021

Copyright $\odot 2021$ by author(s) and Scientific Research Publishing Inc. This work is licensed under the Creative Commons Attribution International License (CC BY 4.0).

http://creativecommons.org/licenses/by/4.0/

\begin{abstract}
Total or partial thyroidectomy has been proposed as the initial treatment for benign euthyroid oiter. The aim of this study is to determine the complications associated with surgical procedures for goiter, based on our experience. Material and method: A retrospective study over 10 years concerning 409 patients operated on for goiters in the department with 48 cases of complications. Results: 409 patients operated on for goiter in the department with 48 cases of complications (11.82\%). The per- and post-operative complications were: hemorrhage (18: 4.40\%), recurrent lesions $(1 ; 0.24 \%), 8$ cases of infection $(1.96 \%), 5$ cases of transient hypocalcemia $(1.22 \%)$ and phonation disorders 9 cases $(2.20 \%)$. Conclusion: Complications from goiter surgery seem to be more related to thyroid disease and the surgeon's experience than to the surgical procedure. Better knowledge of the factors leading to complications will improve the outcome of goiter surgery.
\end{abstract}

\section{Keywords}

Goiter, Complications, Surgery, Bamako

\section{Introduction}

Thyroidectomy is considered a surgical procedure with a low incidence of definitive complications [1]. In France 50,000 thyroidectomies are performed each year according the national hospital assessment agency [2]. Thyroidectomy accounted for $5.9 \%$ of surgeries in "A" surgery at Point G University Hospital in Mali in 2019. Two major postoperative complications are classic and specific, due to the anatomical relationship of the gland with the laryngeal nerves and the parathyroids [3]: hypocalcaemia and recurrent paralysis, the incidence of which 
is approximately $20 \%$ to $30 \%$ and $5 \%$ to $11 \%$, respectively. Although their rate is less than $0.1 \%$, the occurrence of recurrent bilateral adduction paralysis or a compressive hematoma can be life-threatening and require emergency management [4].

Prevention of complications requires a careful resection technique and for some teams by the use of specific techniques such as recurrent neuromonitoring (NIM) [5].

Compensation for hypocalcaemia is based on the administration of calcium, possibly coupled with vitamin $\mathrm{D}$, for at least ten days. Recurrent paralysis recovers in the majority of cases, and no invasive therapy should be performed for six months except in emergencies [6]. Laryngeal surgery techniques allow a notable improvement if, after six months, the phonatory or respiratory sequelae are major, but their result is inconsistent [7]. The detection of a complication after thyroidectomy, must be systematic and their management multidisciplinary.

The objective of this study is to determine the complications associated with goiter surgery in the A surgery department at the G-spot CHU.

\section{Material and Methods}

This was a retrospective and descriptive study carried out in the " $\mathrm{A}$ " surgery department of the CHU of POINT G from January 2007 to August 2017. All the patients referred or received and operated on for goiters including the consequences were complicated intraoperatively or postoperatively. Patients with simple postoperative effects were not included in the study.

The information was obtained through: the patient register, the operating report and the patient file. The parameters studied were: The sex, the size of the goiter, the surgical techniques used, the complications occurring during and after the operation, the mortality linked to the thyroidectomy.

The variables were studied by the software IBM SPSSSTATISTICS VERSION 20.

\section{Results}

Out of a total of 409 patients operated on for goitres in the department, we colligated 48 patient files $(11.82 \%)$ having presented one or more complications. The sex ratio was 7.6 in favor of women. The size of the goiter is greater than 8 $\mathrm{cm}$ in 124 patients (30.32\%). ASA I and ASA II patients were in the majority (248 cases; $60.63 \%$, and 120 cases; $29.33 \%$ ). The size of the goiter measured on the transverse diameter varied from $4 \mathrm{~cm}$ to $8 \mathrm{~cm}$ in 200 patients (48.90\%). It was greater than $8 \mathrm{~cm}$ in 124 patients (30.32). The surgical techniques used were subtotal thyroidectomy $(226 ; 55.25 \%)$, isthmo-lobectomy $(145 ; 32.54 \%)$, total thyroidectomy $(114 ; 3.41 \%)$. The surgical techniques are summarized in Table 1. Complications that occurred intraoperatively were haemorrhage $(18 ; 4.40 \%)$, recurrent lesions $(1 ; 0.24 \%)$. The complications that occurred immediately after the operation were made up of 8 cases of infection (1.96\%), 5 cases of transient 
Table 1. Distribution according to surgical technique.

\begin{tabular}{ccc}
\hline Surgical technique & $\mathrm{N}$ & Percentage \\
\hline Subtotal thyroidectomy & 226 & $55.25 \%$ \\
Isthmo-lobectomy & 145 & $32.54 \%$ \\
Total thyroidectomy & 114 & $3.41 \%$ \\
\hline
\end{tabular}

hypocalcemia (1.22\%), hemorrhage (requiring revision for hemostasis). Phonation disorders were noted in 9 cases (2.20\%). We recorded 6 deaths (1.47\%). Complications that have arisen intraoperatively are summarized in Table 2 . We recorded 6 deaths $(1.47 \%)$.

\section{Discussion}

\subsection{Frequency}

The complication rate of $11.74 \%$ is higher than those found by some authors [5] [6] [8] [9] [10]. There is a statistically significant difference $(\mathrm{P}<0.05)$. This could be explained by the fact that their study focused on cases of hyperthyroid goitre mainly on the one hand and the small size of their sample on the other.

\subsection{Age}

The 40 - 59 age group was most affected by bleeding complications, which was compliant with the mean age (42.29) years with a standard deviation of 13.76;

The average age of 42.29 years does not differ statistically from that of African authors [3] [11]. Goiter appears to be a pathology of young adults. There is a statistically significant difference with the mean age of 51 reported by Rios [12]. This could be explained by the youth of the African population.

\subsection{Gender}

The relationship between gender and the occurrence of complications has not been established. The female sex was the most affected with a ratio of 7.18. This trend has been found by several authors at the national and international level [3] [9] [11]. Female sex is a risk factor for thyroid disease [9]. The strong female predominance is probably due to the action of estrogen during puberty. The thyroid has receptors for these female hormones which decrease the penetration of iodine into the gland. The role of pregnancies is also mentioned, the thyroid cells of fetus, once the pregnancy is terminated, causes an autoimmune reaction in the gland [13].

\subsection{Technique and Complications}

The surgical techniques used were sub-total thyroidectomy (226; 55.25\%), isthmolo-bectomy $(145 ; 32.54 \%)$, total thyroidectomy $(114 ; 3.41 \%)$. No significant difference appeared concerning recurrent and parathyroid complications between the 3 surgical procedures. Total thyroidectomy presents a morbidity similar 
Table 2. Breakdown by complications.

\begin{tabular}{ccc}
\hline Type of complications & $\mathrm{N}$ & Percentage \\
\hline Hemorrhage & 18 & $4.40 \%$ \\
Phonation disorders & 9 & $2.20 \%$ \\
Infection & 8 & $1.96 \%$ \\
Transient hypocalcaemia & 5 & $1.22 \%$ \\
Recurrent lesions & 1 & $0.24 \%$ \\
\hline
\end{tabular}

to that of subtotal thyroidectomy and lobectomy in benign nodular pathology [8]. It also prevents recurrence of which surgical revisions are difficult. Admittedly, it involves a life-long replacement opotherapy that other surgical techniques can nevertheless not always avoid? Henceforth, total thyroidectomy is, for the authors, the treatment of choice in the surgical management of benign multinodular goiters [9]. In all cases, the decision should be consensual between the patient, the endocrinologist and the surgeon.

\subsection{Hemorrhage}

The hemorrhage rate of (4.40\%) does not differ some $6.2 \%$ found by Koumaré $\mathrm{S}$ [10], but higher than those of Marrakech in 2010 [13]. and Togo [11] in the same year in CHU Gabriel who found $1.2 \%$ and $1.5 \%$ respectively. This could be explained by the fact that their study focused on cases of hyperthyroid goiters mainly on the one hand and the small size of their sample on the other hand $(\mathrm{p}<$ 0.05). This complication is most often secondary to surgery for a large goiter (you will find the preoperative, intraoperative and postoperative images of a large goiter in Figures 1-3 or a goiter for Graves' disease, to the release of a vascular section frame, but also to the surgeon's experience [14].

\subsection{Hypocalcaemia}

Transient or definitive parathyroid morbidity after thyroid surgery is a common complication after subtotal or total thyroidectomy. The excision of the parathyroid parenchyma associated with the devascularization of the parathyroid glands at the time of dissection are the mechanisms usually chosen [15]. Hypocalcaemia is a common complication of thyroid surgery. The rate varied from $1.6 \%$ to $50 \%$ according to Jafari [7] and is transient in $1.4 \%$ of cases.

\subsection{Recursive Paralysis}

The rate was $2.6 \%$ in our study. Rosato et al. found a rate of $0.4 \%$ [14]. This paralysis could be explained by an excess of electrocoagulation near the nerve, a stretch of the nerve or even a section. It now seems accepted by most authors that the inferior or recurrent laryngeal nerve must be identified or dissected during a thyroid lobectomy. Identification and dissection would guarantee the anatomical and functional integrity of the nerve [16]. 


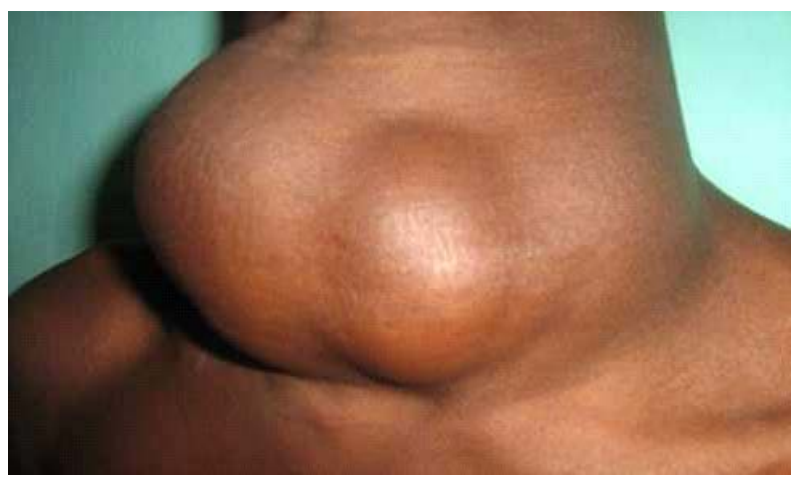

Figure 1. Voluminous multinodular bilateral preoperative goiter. Source: Department of surgery A of the CHU of POINT G.

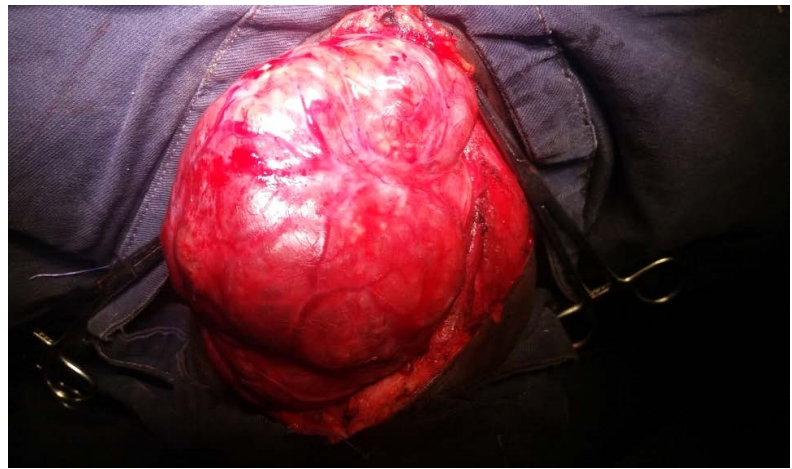

Figure 2. Exposure of bilateral multinodular goiter intraoperatively. Source: Department of surgery A of the CHU of POINT G.

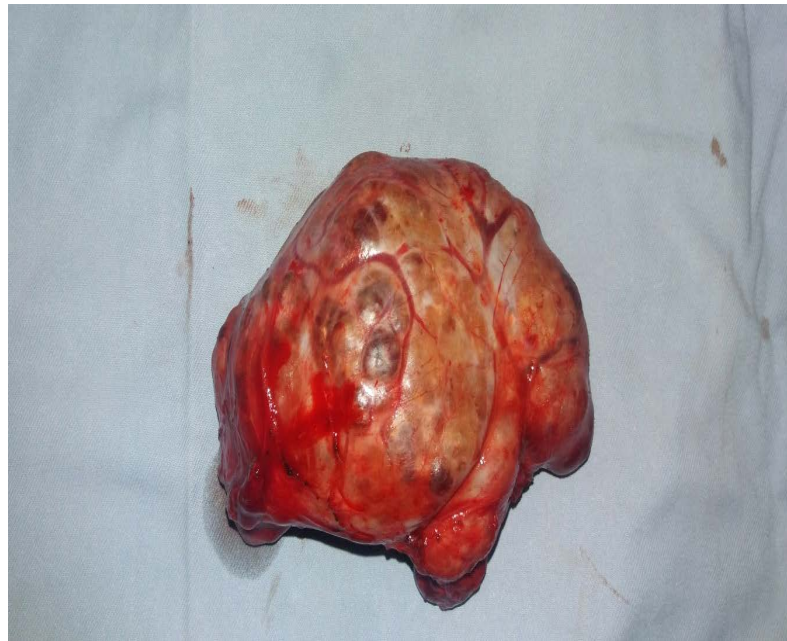

Figure 3. Operative part of a total thyroidectomy for large bilateral multinodular goiter. Source: Department of surgery A of the CHU of POINT G.

\subsection{Infection}

Thyroid surgery is classified as Altemeier type I. Wound infection is exceptional (less than 1\%) in the literature [17]. We identified 8 cases (2\%) of postoperative infection. This rate was $0.75 \%$ according to ZIRARI in Marrakech. Six deaths 
were recorded $(1.7 \%)$ including two from hemorrhage and four from neoplastic complications.

Limitations of the study were marked by: incomplete records; the inaccessibility of some patients after discharge; the unavailability of certain additional emergency examinations.

\section{Conclusions}

Goiter surgery is a regular practice in our department. Surgical procedures are in the majority of cases straightforward.

Hyperthyroid goiters must be balanced before any surgery to avoid complications.

\section{Conflicts of Interest}

The authors declare no conflicts of interest regarding the publication of this paper.

\section{References}

[1] Christou, N. and Mathonnet, M. (2013) Complications after Total Thyroidectomy. Journal of Visceral Surgery, 150, 249-256.

https://doi.org/10.1016/j.jviscsurg.2013.04.003

[2] 2012 French Technical Agency for Hospitalization Information. http://www.atih.sante.fr

[3] Sanogo, Z.Z., Koïta, A.K., Koumaré, S., Keïta, S., Saye, Z., Camara, M., Doumbia, D., Ouattara, M., Togo, S., Yéna, S. and Sangaré, D. (2012) Prise en charge chirurgicale des goitres hyperthyroïdiens à Bamako. Le Mali Medical, 27, 1-4.

[4] Dener, C. (2002) Complication Rates after Operations for Benign Thyroid Disease. Acta Oto-Laryngologica, 122, 679-683. https://doi.org/10.1080/000164802320396394

[5] Ducarme, G., Bertherat, J., Vuillard, E., Polak, M., Guibourdenche, J. and Luton, D. (2007) Pregnancy and Thyroid Disorders. La Revue de Medecine Interne, 28, 314 321. https://doi.org/10.1016/j.revmed.2007.01.011

[6] Langley, R.W. and Burch, H.B. (2003) Perioperative Management of the Thyrotoxic Patient. Endocrinology \& Metabolism Clinics of North America, 32, 519-534. https://doi.org/10.1016/S0889-8529(03)00010-0

[7] Jafari, M., Pattou, F., et al. (2002) Early Prediction of Outcome of Permanent Hypocalcemia after Bilateral Thyroid Resection: A Prospective Cohort Study. Annales de Chirurgie, 127, 612-618. https://doi.org/10.1016/S0003-3944(02)00821-0

[8] Ayache, S., Tramier, B., Chatelain, D., Mardyla, N., Benhaim, T. and Strunski, V. (2005) Evolution de la chirurgie thyroïdienne vers la thyroïdectomie totale: A propos de 735 cas. Annales d Otolaryngologie et de Chirurgie Cervico-faciale, 122, 127 133. https://doi.org/10.1016/S0003-438X(05)82337-0

[9] Trésallet, C., Chigot, J.P. and Menegaux, F. (2005) How to Prevent Recurrent Nerve Palsy during Thyroid Surgery? Annales de Chirurgie, 131, 149-153. https://doi.org/10.1016/j.anchir.2005.09.002

[10] Koumaré, S., Soumaré, L., Sacko, O., Camara, M., Koïta, A., Keïta, S., Camara, A., Sissoko, M., Togo, S., Ouattara, M.A., Dicko, H., Coulibaly, B., Singaré, K., Dem- 
bele, A., Sanogo, Z.Z. and Sangaré, D. (2016) Management of Goiters in the Surgery a Department of the Point G university Hospital. Le Mali Medical, 31, 13-17.

[11] Togo, A., Samaké, B.M., Kanté, L., Traoré, A., Diakité, I., Dembélé, B.T., et al. (2013) Benign Hyperthyroid Goiter in the General Surgery Department of CHU Gabriel Touré. African Journal of Surgery, 2, 122-126.

[12] Dieng, M., Cissé, M., Ndour, M.D., et al. (2010) Indications and Results of Thyroidectomies Performed in a General Surgery Department. About 402 Operated Patients. Revue Africaine de Chirurgie et Spécialités, 4, 1-8. https://doi.org/10.4314/racs.v4i9.69961

[13] Zirari, W. (2010) Complications of Thyroid Surgery at the Faculty of Medicine and Pharmacy at Cadi Ayyad University in Marrakech in 2010.

[14] Rosato, L., Avenia, N., Bernante, P., et al. (2004) Complications of Thyroid Surgery: Analysis of a Multicentric Study on 14,934 Patients Operated on in Italy over 5 Years. World Journal of Surgery, 28, 271-276. https://doi.org/10.1007/s00268-003-6903-1

[15] Tomusch, O., Machens, A., Sekulla, C., Ukkat, J., Brauckhoff, M. and Dralle, H. (2003) The Impact of Surgical Technique on Postoperative Hypoparathyroidism in Bilateral Thyroid Surgery: A Multivariate Analysis of 5846 Consecutive Patients. Surgery, 133, 180-185. https://doi.org/10.1067/msy.2003.61

[16] Proye, C., Patoir, A., Trincaretto, F., Darras, J. and Lagache, G. (1980) Valeur de la dissection systématique du nerf récurrent en chirurgie thyroïdienne. 428 thyroïdectomies en. Journal de Chirurgie, 117, 155-160.

[17] Ould-Ahmed, M. (2006) Recurrent Laryngeal Nerve Injury after Thyroidectomy and Preoperative Nerve Monitoring. Annales Françaises d Anesthésie et de Réanimation, 25, 902-910. 